\section{AL-AZHAR}

Assiut Dental Journal
The Official Publication of The

Faculty of Dental medicine.

Al-Azhar Assiut Uniuersity.

AADJ, Vol. 3, No. 2, October (2020) - PP. 155:162

ISSn 2682-2822

\title{
Histological Evaluation of The Effect of Pilocarpine on the Lingual Salivary Glands of The Root of the Tongue After X-Ray Irradiation in Rats
}

\author{
Hesham A. Dameer ${ }^{1}$, Hany G. Gobran*1, Mohamed G. Khalil ${ }^{2}$
}

Codex : 19/2020/10

Aadj@azhar.edu.eg

\section{KEYWORDS}

Radiation , Pilocarpine,

Lingual salivary glands ,

Degeneration, Acinar cells

1. Department of Oral Biology, Faculty of Dental Medicine, (Cairo, boys), Al-Azhar University, Egypt.

2. Department of Oral pathology, Faculty of Dental Medicine, (Assuit, boys), Al-Azhar University, Egypt.

* Corresponding Author e-mail: hanygobran77@azhar.edu.eg

\begin{abstract}
Aim: The aim of this study was to evaluate the effect of pilocarpine on the histological changes, induced by exposure to radiation therapy, in the rat's lingual salivary glands. Subjects and methods: This study was carried on 30 adult male SpragueDawley rats weighing 150-250 g. That the rats were divided into 3 groups (10 rats per each). Group I: Control group received neither radiation nor drug. Group II: exposed to a single whole body $\gamma$-irradiation at dose of 6 Gray (Gy). Group (3): the rats were injected intraperitoneally by a single dose of pilocarpine hydrochloride $(0.2 \mathrm{mg} / \mathrm{kg})$ 90 minute before the exposure of the previous dose of radiation. Results: One week after x-ray radiation the glands demonstrated marked destructive changes. These changes comprise in the form of loss of acinar architecture, and acinar degeneration and atrophy. Pilocarpine administration prior to radiation has decreased, but not completely prevents, the harmful effects of radiation. The radioprotective effect of pilocarpine treatment was manifested by the decreased atrophic changes and the absence of degenerated acinar cells. Conclusion: Administration of pilocarpine can protect, to some extent, the lingual salivary glands against radiation histological damage.
\end{abstract}

\section{INTRODUCTION}

Head and neck cancer is the sixth most common malignancy worldwide. ${ }^{(1)}$ Each year about 500,000 patients world-wide were treated for head and neck cancer. The majority of these patients were treated with radiotherapy either alone or in combination with other treatment modalities such as surgery and/or chemotherapy. ${ }^{(2,3)}$ Radiation therapy has been used effectively in treating head and neck cancers for many decades; it is used to cure cancer and also to alleviate cancer-associated symptoms. ${ }^{(4)}$ The use of radiation as a therapeutic measure leads to significant alterations that occurs not only in cancer cells but also in healthy tissues. It causes also unwanted symptoms during and after the treatment, including dry mouth or xerostomia, mucositis, dental carries, difficulty in swallowing, and eventually inadequate 
feeding. ${ }^{(5)}$ Therefore, xerostomia significantly impairs patients' quality of life and can compromise the continuity of their cancer treatment. ${ }^{(6)}$ Several studies have shown significant improvement in radiation induced xerostomia when pilocarpine was given along with radiotherapy ${ }^{(7)}$.

Pilocarpine pretreatment was also proved as protective agent against irradiation, displaying much less damage after irradiation of the same dosage. ${ }^{(8)}$

Pilocarpine is a naturally occurring compound derived from the South American shrub Pilocarpus jaborandi. This plant alkaloid is acholinergic para sympathomimetic agonist that binds to muscarinic-M3 receptors and can cause pharmacological smooth muscle contraction in humans and stimulation of various exocrine glands. ${ }^{(9)}$ Pilocarpine hydrochloride (Salagen) are currently indicated for treatment of radiation-induced dry mouth. ${ }^{(10)}$

In a previous study) use of pilocarpine provided significant relief to patients with radiation-induced dry mouth. They demonstrated that, the use of pilocarpine significantly improved symptoms of intraoral dryness, oral discomfort, and dysphonia and patients' global assessment of dry mouth as well as reduced the need for administration of oral comfort agents such as artificial saliva, water, and hard candy. The patients also demonstrated a statistically significant increase in saliva production, measured as either whole-mouth or parotid salivary flow. It is through this mechanism that cholinergic stimulation of residual-functioning exocrine glandular tissue in patients There have been many animal studies on the effect of radiation on the major salivary glands ,however no studies reported in regard to the effect of radiation on the lingual salivary glands ${ }^{(11)}$.The aim of this study was to evaluate the histological alterations that occur in the lingual salivary glands acinar cells of rats subjected to radiation with or without pilocarpine pretreatment .

\section{MATERIALS AND METHODS}

\section{Experimental animals:-}

30 adult male Sprague- Dawley rats weighing 150-250 $\mathrm{g}$ were used in this investigation. The procedure and management were carried out at the animal house of National Center of Radiation Research and Technology (NCRRT), Cairo, Egypt.

The experiment was performed after accommodation period in the laboratory environment for 7 days. The rats were housed in a room with controlled temperature $25^{\circ} \mathrm{C} \pm 2^{\circ} \mathrm{C}$, humidity $50 \% \pm$ $5 \%$, and about 12-hour light/dark cycle and were fed on chew and water ad labium.

\section{Grouping and drug administration:}

The animals were divided randomly into 3 main groups as follows:

Group (I): the control group consisted of 10 rats used as control for the other group of animals, and received neither radiation nor drug.

Group (2): consisted of 10 rats will be exposed to a single whole body $\gamma$-irradiation at dose of 6 Gray (Gy).

Group (3): consisted of 10 rats injected intraperiotonial by a single dose of pilocarpin $(0,2 \mathrm{mg} /$ kg) (Sigma Chemical Co., St. Louis, MO) dissolved in $1 \mathrm{ml}$ of normal saline then exposed to a single whole body $\gamma$-irradiation at dose of 6 Gray (Gy).

\section{Irradiation Technique:-}

The whole body irradiation of animals was performed at National Center of Radiation Research and Technology (NCRRT), Cairo, Egypt, using Gamma cell 40. Gamma cell 40 is a Cesium 137 irradiation unit manufactured by Atomic Energy of Canada Limited (AECL) and designed for use in an unshielded room. The unit provides a mean for a uniform gamma irradiation of small animals or biological samples while providing adequate ventilation for experimental animals and complete protection for operating personnel. 
The Cesium 137 source provides a dose rate of $6 \mathrm{~Gy} / \mathrm{min}$.

For the study of the lingual salivary glands ,the root of the tongue were processed microtechnically, embedded in paraffin wax and the sections were cut at 5-7 $\mu \mathrm{m}$ thick and prepared for studding with hematoxylin and eosin stain.

\section{RESULTS}

\section{Group (I): the control group (no-irradiation)}

A) Von-Ebner's gland is a serous gland, located under the circumvallate papillae in the lamina propria of the tongue and extend deeply in the submucosa until reach to the muscular layers. Their ducts open at the bottom of the groove surrounding the circumvallate papillae. The lobules were seen separated from each other by muscles bundle, adipose tissue and little amount of loose connective tissue which rich in blood vessels and nerve fibers. The lobules consist of densely packed acini cells, lined by pyramidal cells. The serous acini cells have a rose shape with narrow lumen, stained darkly with (H\&E) stain from pink to purple (Fig 1,A)

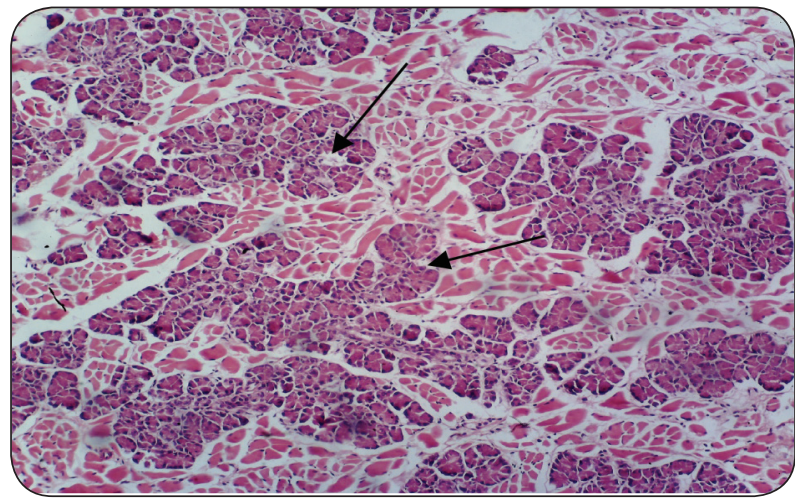

Fig. (1A) Photomicrograph of the Von-Ebner's gland showing the lobules which separated from each other by muscle bundle, adipose tissue and little amount of loose connective tissue.

B) The Weber's gland is a mucous gland, found in the root of the tongue. The glands have a vari- able number of lobules which present within lamina propria as well as extending to the muscular layer and open in the epithelial surface of the tongue in the root region, some of lobules located deeply to Von Ebner's glands in the muscular layer. The lobules are different in size and shape, supported by a loose connective tissue which contains collagen fibers, blood vessels, nerve fibers, and adipose tissue separating between the lobules. Each lobule consists from densely packed mucous acini lined by relatively large pyramidal cells and has small round nuclei located at the base of cell near the basement membrane. A small lumen seen in the center of acini .

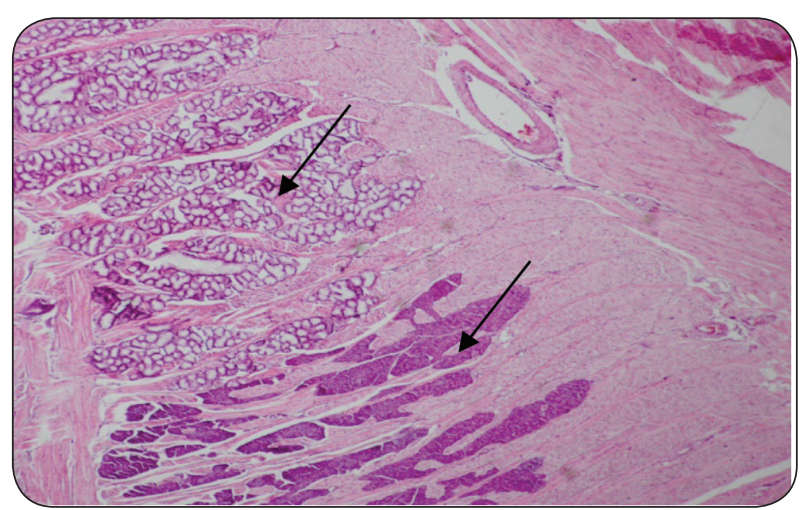

Fig. (1B) Photomicrograph of Weber's gland showing variable number of glandular lobule which extend between the tongue muscles. Each lobule consist from densely packed mucous acini. (H\&E stain $\mathrm{x} 100)$

\section{Group (II): (rats exposed to a single dose of irradiation)}

$(\mathbf{A} \& \mathbf{B})$ The serous acini of Von-Ebner's gland was the most affected cells by radiation. The radiation provoked many destructive changes in the glands. These changes comprise loss of normal architecture, acinar atrophy , acinar degeneration and deeply-stained variable-sized nuclei. The acinar atrophy was manifested in the gland in the form of increased interacinar spaces. The acinar degeneration was represented as empty spaces in the acinar lobules . Some areas of the tongue noted with dilat- 
ed blood vessels. Extravasated red blood cells also seen . Marked inflammatory cell infiltration were also noted (Fig. 2,A\&B).

(C\& D) The mucous acini of the Weber gland appeared more resistant to the degenerative changes of exposure to radiation. However, some acinar cells revealed areas of degeneration ,marked enlargement of the acini and loss of normal architecture. The nucleus of the acinar cell appeared displaced basally . ( Fig2, C\&D ).
Group (III): ( rats injected with a single dose of pilocarpin and then exposed to a single whole body $\gamma$-irradiation at dose of 6 Gray (Gy):-

(A) The serous acini of Von-Ebner's gland demonstrated mild acinar degeneration and the acinar architecture was slightly altered. The nuclei of acinar cells were deeply stained. Fig $(3, \mathrm{~A})$.

(B) The mucous acini of the Weber gland demonstrated slight enlargement. The gland demonstrated intact acinar architecture with neither acinar atrophy nor acinar degeneration. Fig $(3, \mathrm{~B})$.
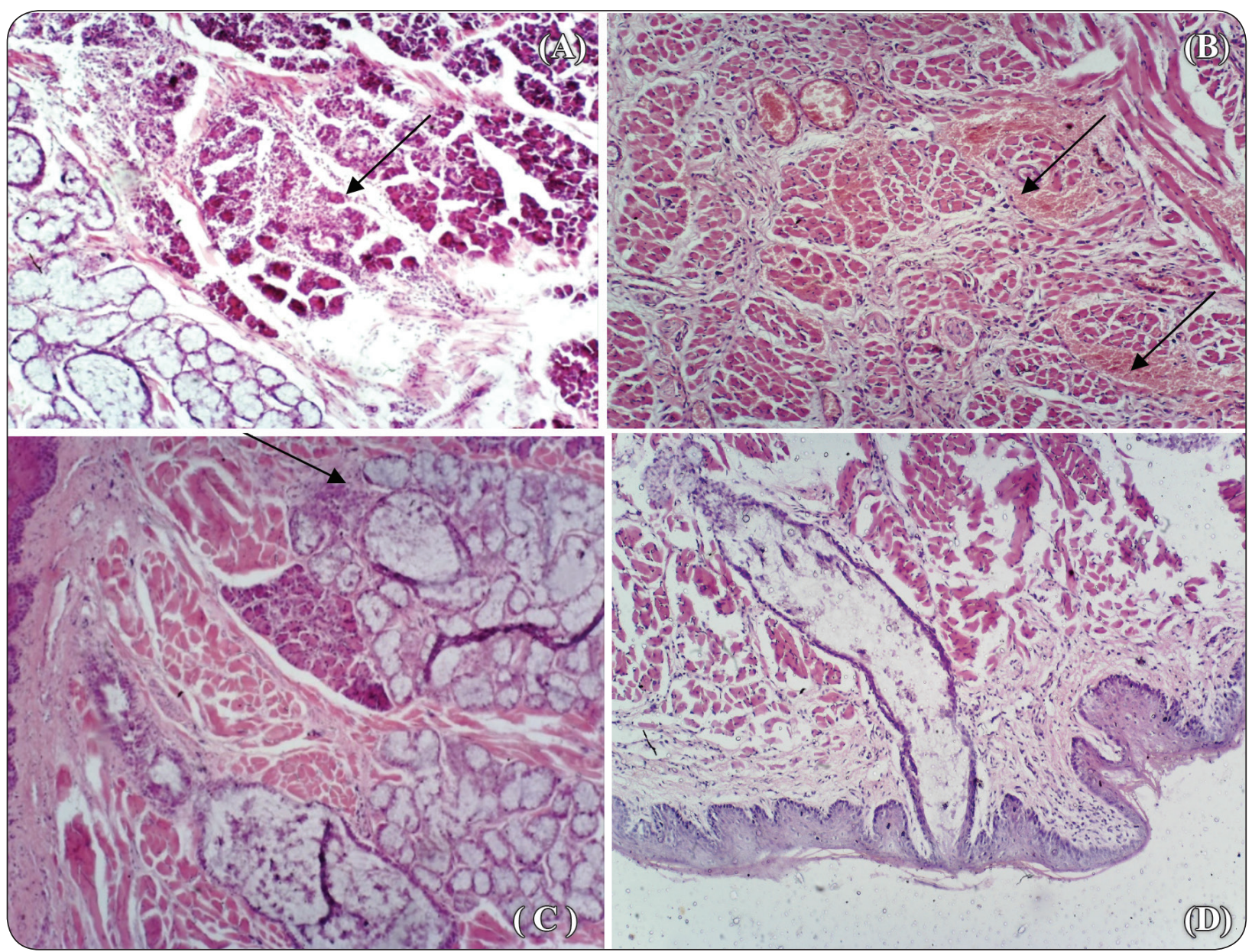

Fig. (2) (A\&B) the Von-Ebner's gland showing severe acinar atrophy and acinar degeneration with empty spaces in the acinar lobules due to loss of some acini, remnant of degenerated acinar cells and marked inflammatory cell infiltration . Dilated blood vessels containing RBCs. and extravasated red blood cells also seen (H\&E x200)

Fig. (2) (C\&D) Photomicrograph of group II showing areas of mild acinar degeneration and dilated large duct opening on the dorsal lingual surface. (. H\&E stainx200) 


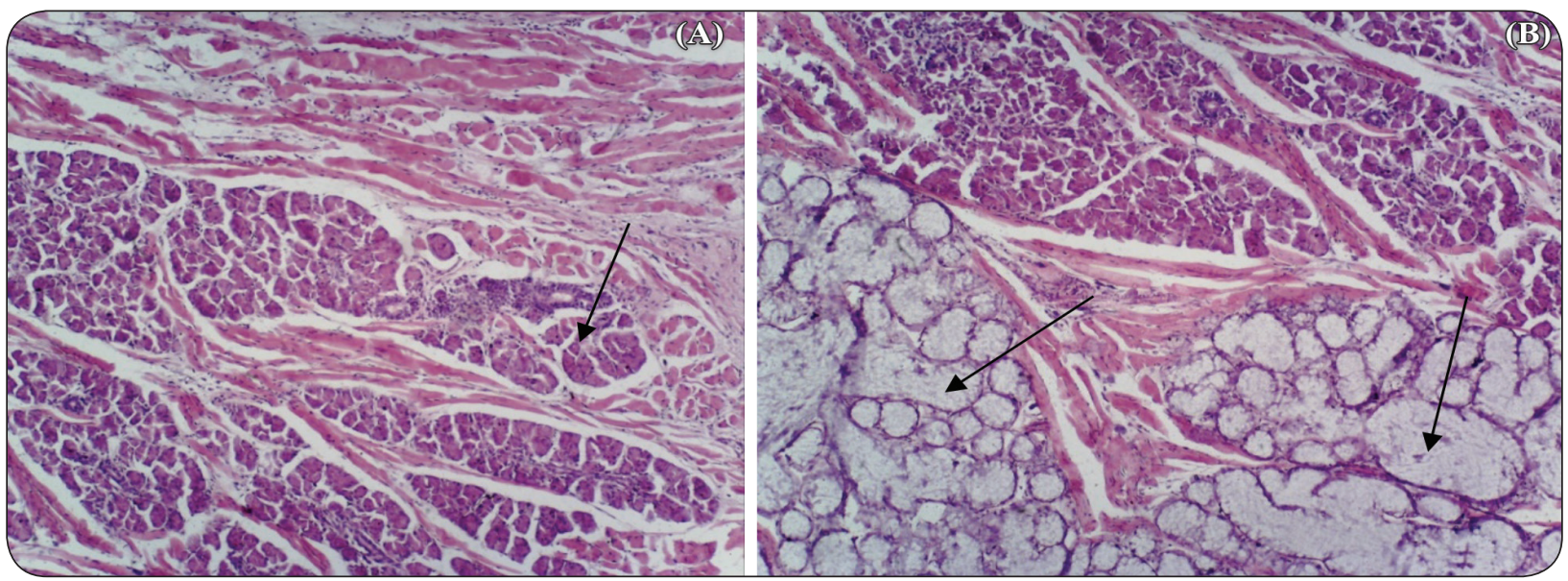

Fig. (3,A)Photomicrograph of group III showing mild acinar degeneration and the acinar architecture was slightly altered . (B)The mucous acini of the Weber gland demonstrated slight enlargement. H\&E stainx200

\section{DISCUSSION}

The radioprotective effect of many materials against salivary glands dysfunction were studied . in this study we try to observe the radio protective effect of pilocarpine on the lingual salivary glands of the rats . The present study demonstrated many degenerative changes in the lingual salivary glands when they are exposed to radiation.

The secretory granules content of the serous cells in the Von-Ebner's gland in the present study were reduced by radiation. Similar results were also reported in the granular convoluted tubules of the submandibular gland by Vissink et al., (1991 ) ${ }^{(12)}$

The radiation has induced destructive changes in the investigated salivary glands,which are demonstrated in the form of massive injuries of both the acinar and ductal architecture as the acinar atrophy, intracytoplasmic vacuolation and degeneration with nuclear changes including the pleomorphism and hyperchromatism. These findings were comparable with those reported in the previous studies among. ${ }^{(13)}$

The observed atrophic changes of serous acini in the Von Ebner gland were also documented on the parotid and the submaxillary glands by Ahlner et al. ${ }^{(14)}$.
The early response resulting in the atrophic changes of the secretory cells, without inflammation were presumed to be due to radiation-induced apoptosis, while the late response with inflammation could be the result of radiation-induced necrosis. ${ }^{(15)}$ Other investigators, however, have proposed that the progressive loss of acini in the parotid and submandibular glands can be correlated to the activation of mast cells and the release of their secretory products.$^{(16)}$

In the present study, the serous acinar cells were demonstrated to be highly sensitive to irradiation and these results are consistent with those observed by Nagler ${ }^{(17)}$ in the submandibular and sublingual salivary glands of rats.

The mechanism by which this occurs is controversial and not clear however, it has been suggested that the serous secretory granules have proteolytic and metallic transmission enzymes. The transmission materials are known to promote the formation of the free radicals, thereby, potentiating the damage to the serous granule membranes. As a result, the proteolytic enzymes may infiltrate and damage the cytoplasm, causing autolysis and cellular death. ${ }^{(164)}$

The improved salivary gland function has been observed in rats when degranulation was stimulated 
by pilocarpine administration prior to the radiation exposure. ${ }^{(17)}$ The involvement of the serous secretory granules associates with the increased damage caused by ionizing radiation was further confirmed by ${ }^{(18,19)}$

In the present study, the pilocarpine administration prior to radiation have decreased the harmful effects of radiation. However, the administration of pilocarpine not completely prevent all the radiationinduced pathological alterations. The radioprotective effect of pilocarpine treatment was manifested by the decreased atrophic changes and the absence of degenerated acinar cells.

The salivary glands have been suggested to have dual innervation, the parasympathectomy witch prevents the attainment of the adult gland size, the normal proliferation and the DNA and RNA content, while the sympathectomy has only moderate influence on the cells and gland size. ${ }^{(20)}$

The pilocarpine hydrochloride is known as a cholinergic parasympathomimetic agent exerting a broad spectrum of pharmacologic effect with predominant muscarinic action and in appropriate dosage it can increase the secretion of exocrine glands. ${ }^{(21)}$

Greenspan and Daniels ${ }^{(22)}$ observed expulsion of secretory granules from the serous cells in exocrine fashion by pilocarpine. The pilocarpine, a parasympathetic agonist, has been found to effectively stimulate salivation of the rat 30 to 60 minutes after injection. ${ }^{(23)}$ Histologically, the pilocarpine has been proven to cause moderate depletion of granules. Whereas the atropine increased the amount of granules. The results showed that the salivary glands in pilocarpine-pretreated group of animals was less damaged by irradiation than those without pilocarpine treatment .

\section{REFERENCES}

1. Parkin DM, Bray F, Ferlay J, et al. Global cancer statistics, 2002. CA Cancer J Clin. 2005;55(2):74-108.

2. Vissink A, Burlage FR, Spijkervet FK, Jansma J, Coppes RP. Prevention and treatment of the consequences of head and neck radiotherapy. Crit Rev Oral Biol Med. 2003;(14):213-225.

3. Vissink A, Jansma J, Spijkervet FK, Burlage FR, Coppes RP. Oral sequelae of head and neck radiotherapy. Crit Rev Oral Biol Med. 2003;(14):199-212.

4. Mizoe JE, Hasegawa A, Jingu K, et al. Results of carbon ion radiotherapy for head and neck cancer. Radiother Oncol 2012;(103):32-37.

5. Kumar $\mathrm{S}$, Ram S, Navazesh M. Salivary gland and associated complications in head and neck cancer therapy. J Calif Dent Assoc 2011;(39): 639-647

6. Davies AN, Broadley K, Beighton D. Xerostomia in patients with advanced cancer. J Pain Symptom Manage 2001;(22):820-825.

7. LeVeque FG, Montgomery M, Potter D, et al. A multicenter, randomized, doubleblind, placebo-controlled dose titration study of oral pilocarpine for treatment of radiation-induced xerostomia in head and neck cancer patients.J Clin Oncol. 1993; (11):1124-1131.

8. Department of Otolaryngology, Seoul National University, College of Medicine, Korea.The effect of pilocarpine and atropine dministration on radiation-induced injury of rat submandibular glands. Acta Otolaryngol. 1991;111(5):967-73

9. Taylor P. Cholinergic agonists. In: Gilman AG, Rall TW, Nies AS, Taylor P, eds. Goodman and Gilman's: The Pharmacologic Basis of Therapeutics. 8th ed. New York, NY: Pergamon Press Inc; 1990:122-130.

10. Wiseman LR, Faulds D. Oral pilocarpine: a review of its pharmacological properties and clinical potential in xerostomia. Drugs. 1995;49:143-155

11. Johnson JT, Ferretti GA, Nethery WJ, et al. Oral pilocarpine for post-radiation xerostomia in patients with head and neck cancer.N Engl J Med. 1993;329:390-395

12. Vissink A, Kalicharan D, 's-Gravenmade EJ, Jongebloed WL, Ligeon EE, Nieuwenhuis P, Konings AWT. Acute irradiation effects on morphology and function of rat submandibular glands. J Oral Pathol Med 1991b; (20): 449- 456. 
13. Teshima K, Murakami R, Yoshida R, Nakayama H, Hiraki A, Hirai T, Nakaguchi Y,Tsujita N, Tomitaka E, Furusawa M, Yamashita Y, and Shinohara M.: Histopathological Changes in Parotid and Submandibular Glands of Patients Treated with Preoperative ChemoradiationTherapy for Oral Cancer. J. Radiat. Res., 53, 492-496 .

14. Ahlner B H Hagelqvist E Lind M G Ruden B I Irradiation of rabbit submandibular glands Histology and morphometry after 15 Gy Acta Otolaryngol 1993.;(113) 210-219.

15. Grundmann O,Mitchell G and Limesand K.: Sensitivity of Salivary Glands to Radiation from Animal Models to Therapies. J Dent Res. 2009 (10): 894-903.

16. Henriksson R, et al : Increase in mast cells and hyaluronic acid correlates to radiation-induced damage and loss of serous acinar cells in salivary glands: the parotid and submandibular glands differ in radiation sensitivity. Br J Cancer 1994 (69): 320-326.

17. Nagler RM, Laufer D Protection against irradiation-induced damage to salivary glands by adrenergic agonist administration. Int J Radiat Oncol Biol Phys. (1998) (40):477-481
18. Nagler RM. The enigmatic mechanism of irradiation-induced damage to the major salivary glands. Oral Diseases, 2002 ( 8), 141-146

19. Coppes RP and Stokman: Stem cells and the repair of radiation-induced salivary gland damage. Oral Diseases .2002 (17), 143-153

20. Taylor P. Cholinergic agonists. In: Gilman AG, Rall TW, Nies AS, Taylor P, eds. Goodman and Gilman's the pharmacological basis of therapeutics. 8th ed. New York: Pergamon Press, 1990:122-30.

21. Proctor GB and Carpenter GH.: Regulation of salivary gland function by autonomic nerves. Auton Neurosci. 2007 (1):3-18.

22. Lawrence B.: Systemic pilocarpine for treatment of xerostomia.Expert Opin Drug MetabToxicol.2008(4),1333-40.

23. Takakura AC, Moreira TS, Laitano SC, De Luca LA Jr, Renzi A, and Menani JV Central muscarinic receptors signal pilocarpine-induced salivation. J Dent Res , 2003( 82): 993-997 
مجلة أسيوط لطب الأسنان

النشر الرسمي لكلية طب الأسنان جامعة الأزهر أسيوط الكاية

\section{التقييم النسيجي لمدمي تأثير البيلوكاربين علي الغدرد اللعابية اللسانية لجذر اللسان بعد التعرض للأشعة السينية السينية في الفي الفئران \\ هشام أحمد ضمير1، هاني جميل جبران1، محمد جمعة خليل 2

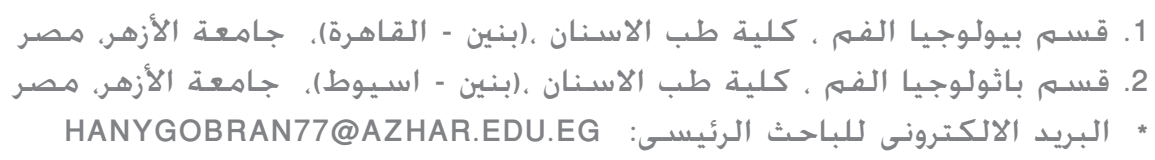

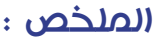

الهـدف : أجريت هذه الدراسـة بهدف دراسـة تأثير البيلوكاربين علي الغدد اللعابية اللسانية لجذر اللسـان في الفئران بعد تعرضها للأشعة

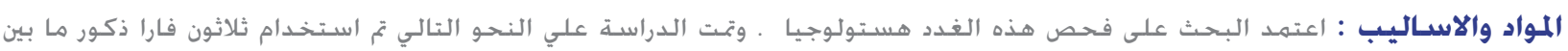

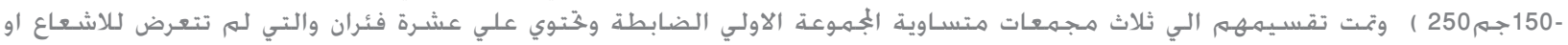

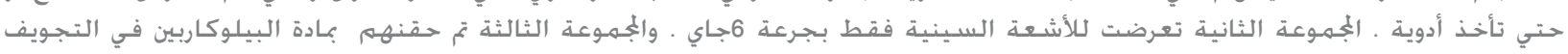

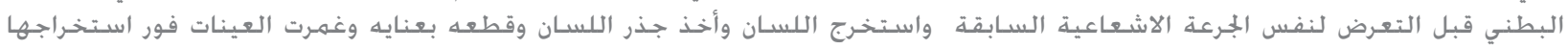

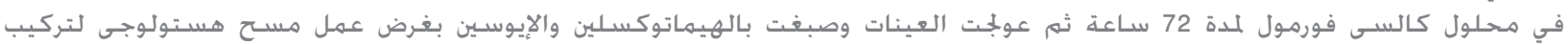

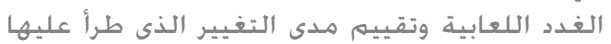

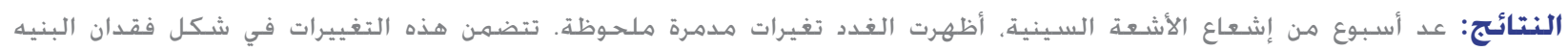

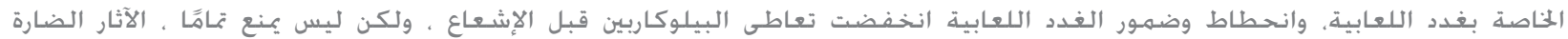

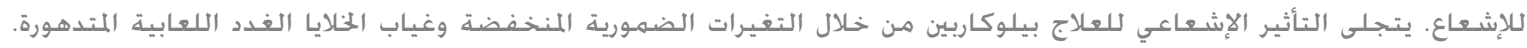

$$
\text { الخلكلاصلة: وقد خلصت الدراسـة إلي فاعلية البيلوكاربين في حماية الغدد اللعابية بعد تعرضها للإشعاع }
$$

